\title{
Regional Disparity in Pakistan's Economy: Regional Econometric Analysis of Causes and Remedies
}

\author{
KHAN M. Tariq Yousuf and Komei SASAKI \\ Graduate School of Information Sciences, Tohoku University, \\ Information Sciences Building, 09 Aoba Aramaki Aoba-ku, Sendai 980-8579, Japan \\ E-mail:tariq@se.is.tohoku.ac.jp,sasaki@se.is.tohoku.ac.jp
}

Received July 2, 2002; final version accepted June 13, 2003

\begin{abstract}
This study analyzes the role of public capital in regional economies and inter-regional economic disparity by means of a regional econometric model for Pakistan. The regional disparity measures show that a sizable disparity in per capita incomes and labor productivity continuously persists among the regions of Pakistan. The efficiency of public capital and private inputs has been analyzed by estimating regional production functions, and the results indicate that the public capital has been more efficiently used in relatively advanced region, whereas a small share of private capital has been allocated to relatively backward region. The tests of technological difference show that the two regions utilize different technologies in their production process, which causes the interregional economic disparity between the regions. The simulation analysis on the basis of the adopted structure of regional econometric model suggests that interregional disparity and the efficiency of the national economy are strongly affected by changing the regional allocation patterns of private capital stock and the level of national public capital.
\end{abstract}

KEYWORDS: public capital, Pakistan economy, regional disparity, capital allocation

\section{Introduction}

Besides Pakistan's many economic problems, interregional disparity is one of the striking issues of the country for which the government of Pakistan is also deeply concerned. Since the issue of interregional imbalances has economic, social and political implications, this study intends to examine the causes of interregional disparity among the regions of Pakistan, and suggest remedies to cure the problem.

In the context of Pakistan, of course several studies have examined the issue of regional disparity in the literature, for example Arshad (1989), Chaudhary (1990), Sampath and Anwer (1996) measured the extent of regional disparity among regions of Pakistan over the time, but those studies generally failed to explain the real economic causes of disparity among regions. Furthermore, only a few studies, for example Looney (1993), De Kruijk (1986), Pasha and Hasan (1982) have incorporated the role of infrastructure investment in economic development and regional issues and they mainly relied on approaches such as factor analysis or Vector Auto Regressions (VARs) models. Recently, Khan and Sasaki (2001) have empirically analyzed the roles of public capital in Pakistan economy on the basis of production function and private investment function.

This study intends to take up the issue of disparity by incorporating infrastructure as an argument and construct regional production, investment, and demographic models in order to examine the causes of and suggest remedies to resolve or minimize interregional disparity in Pakistan.

It is generally hypothesized that the process of economic development may lead to income inequalities among regions. Kuznets (1955) described there exists an inverted U-shaped relation between income equality and economic development. Williamson's (1965) widely cited study generally supports the Kuznets hypothesis for developing economies. Hoover (1971) pointed out that agglomeration economies play an important role in the concentration of economic activities, at a certain location or region. In case of Pakistan since it's inception economic activities are generally concentrated in some specific regions, which facilitated their development relatively faster than the others. The government's provision of infrastructure, which is supposed to promote the productivity of private inputs in most industrial sectors and thereby to stimulate private sector's activities and the pace of economic development, also concentrated to the same preferred regions. Therefore, inadequate provision of public infrastructure hampers the private capital formation and the agglomeration economies in relatively lagging regions, which could be a cause of their underdevelopment.

Pakistan is administratively divided into four regions (provinces), Punjab, Sindh, NWFP (North West Frontier Province), and Balochistan (see Fig. 1), and these regions are highly heterogeneous in terms of size, population, level of economic development, income and labor productivity. The disparity measures, coefficient of variations of per capita income, labor productivity and employment ratio among the four regions ${ }^{(1)}$ shown in Table 1 reveals that the disparity

\footnotetext{
${ }^{1}$ Regional sectoral per capita income, regional sectoral labor productivity and regional sectoral employment ratios are defined as $Y_{r i} / P_{r}, Y_{r i} / L_{r i}$ and
} $L_{r i} / P_{r}$, where $Y_{r i}, L_{r i}$ and $P_{r}$ are regional sectoral income, regional sectoral employed labor force and regional population respectively. 


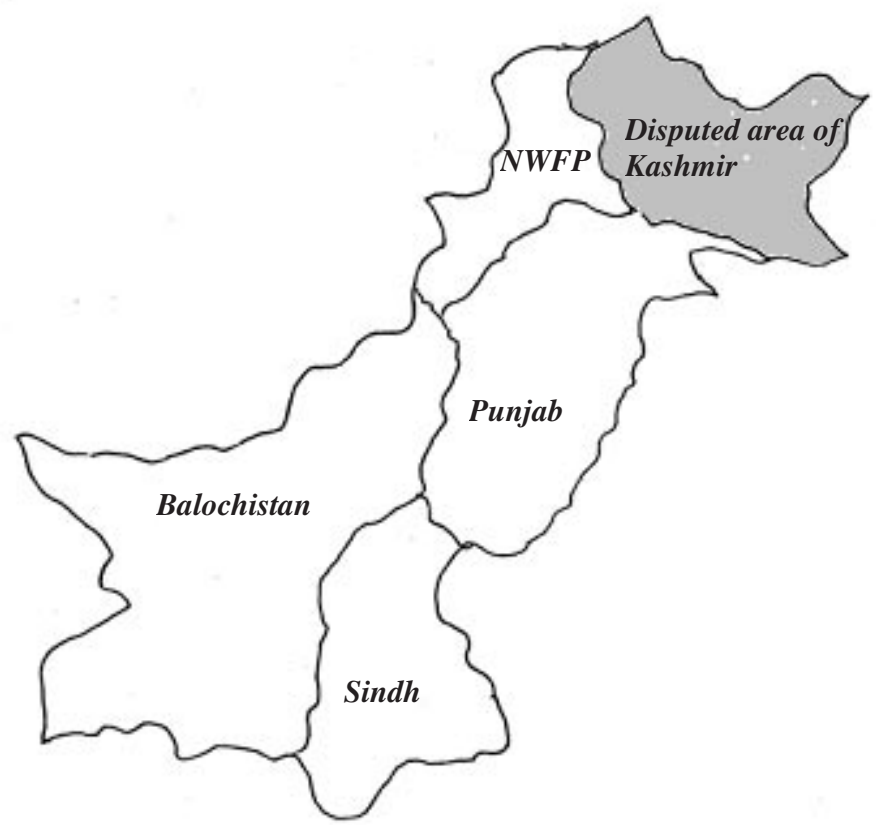

Fig. 1. Regions in Pakistan.

Table 1. Disparity among four regions.

\begin{tabular}{c|cccccccc}
\hline $\begin{array}{c}\text { Coefficient of } \\
\text { variation /Year }\end{array}$ & 1972 & 1975 & 1978 & 1982 & 1986 & 1990 & 1995 & 1997 \\
\hline Per capita GDP & 0.276 & 0.228 & 0.240 & 0.277 & 0.306 & 0.280 & 0.284 & 0.281 \\
Labor productivity & 0.161 & 0.142 & 0.166 & 0.210 & 0.249 & 0.223 & 0.233 & 0.234 \\
Employment ratio & 0.127 & 0.115 & 0.098 & 0.105 & 0.133 & 0.222 & 0.294 & 0.293 \\
\hline
\end{tabular}

Source: calculated by the authors.

Table 2. Average growth rate of per capita income among four regions (\%).

\begin{tabular}{c|cccc|c}
\hline Year & Punjab & Sindh & NWFP & Balochistan & $\begin{array}{c}\text { National } \\
\text { Average }\end{array}$ \\
\hline $1972-77$ & 2.09 & 0.43 & 1.04 & -0.26 & 1.25 \\
$1977-85$ & 3.62 & 4.58 & 4.27 & 0.70 & 3.90 \\
$1985-90$ & 2.27 & 2.64 & 4.27 & 3.44 & 2.68 \\
$1990-97$ & 1.99 & 1.71 & 1.64 & 1.53 & 1.85 \\
$1972-97$ & 2.58 & 2.54 & 2.89 & 0.49 & 2.55 \\
\hline
\end{tabular}

Source: calculated by the authors

in per capita income fluctuates during 1972 to 1997 between 0.27 and 0.28 , showing a slightly upward trend. The coefficients of variation of labor productivity and employment ratio among regions indicate increasing trend.

Table 2 indicates the tendency in the growth of per capita income in regions. Form the Table it is clear that during different time periods the average growth rate of per capita income in Balochistan region is relatively lower than other three regions. Unless some policy measures are under-taken to boost up economic activities in this particular region, the growth rate of per capita income will remain lower relative to other regions.

We also grouped the regions into two broad categories, namely relatively advanced regions and backward regions. Sindh and Punjab are referred to as relatively advanced region while Balochistan and NWFP, as relatively backward region. The disparity measures are reported in Table 3, which indicates that disparity in the case of two regions is relatively smaller than the four-region case, although the pattern is almost the same. The difference in the size of regional disparity in the two cases is mainly due to specific distribution of population between two-regions and four regions. Comparing the extent of disparity of three different measures, Table 3, indicates per capita income disparity increases from 1975 to 1986 and afterward decreases slightly and it remained at 0.16 during 1997 . Disparity in labor 
Table 3. Disparity between two regions.

\begin{tabular}{l|llllllll}
\hline \multicolumn{1}{c|}{ Disparity/Year } & 1972 & 1975 & 1978 & 1982 & 1986 & 1990 & 1995 & 1997 \\
\hline Per capita GDP & 0.127 & 0.121 & 0.160 & 0.170 & 0.187 & 0.152 & 0.163 & 0.162 \\
Labor productivity & 0.051 & 0.062 & 0.063 & 0.057 & 0.045 & 0.074 & 0.160 & 0.158 \\
Employment ratio & 0.077 & 0.060 & 0.098 & 0.114 & 0.143 & 0.223 & 0.315 & 0.312 \\
\hline
\end{tabular}

Source: calculated by the authors.

productivity remains smaller during 1972 to 1990, and after that it is almost doubled during 1995 and 1997. Similarly the disparity in employment ratio between two regions increases over the time and reached 0.22 in 1990 and remained in the range of 0.31 during 1995 and $1997 .^{(2)}$

It is necessary to analyze the regional disparity issue and its association with economic infrastructure, and how the regional differences in income and labor productivity are associated with the productivity of public stocks and allocation of public and/or private capital stocks. On the basis of such an analysis useful policy measures might be suggested at national and regional level to induce national production and reduce the regional imbalances.

The paper is organized as follows. In Sect. 2 we present a brief discussion about sources and regional data problems. Section 3 analyzes the regional production functions by incorporating public capital stock as an additional argument. Section 4 examines regional population and labor functions. In Sect. 5 we present regional econometric model and simulation results. Finally, Sect. 6 states concluding remarks.

\section{Data: Sources, Stocks Series and Regional Data Problems}

Most of the national and sectoral time series data for the years 1972-97 used in the analysis were collected from secondary sources. The main sources are Pakistan Economic Survey, State Bank of Pakistan Annual Report, United Nations Yearbook on National Accounts Statistics, and Labor Force Survey. ${ }^{(3)}$

The government in Pakistan uses national-sectoral rather than regional-sectoral classification for product accounts. Also regarding the public investment, the federal government allocates funds on sectoral basis rather than on provincial/regional basis. The government typically surveys the situation in the national context and allocates resources to sectors based on its assessment of that sector's potential to contribute to national development. Other considerations are often accorded secondary importance. Under this situation, regional data, especially, on public and private stocks are not available at all. ${ }^{(4)}$

\section{Regional Production Function Analysis}

In the subsequent sections, the disparity between two regions rather than among four regions is analyzed because of the limited data availability. The relatively advanced regions are referred to as Region 1 while the relatively backward regions as Region 2.

We intend to examine to which extent the differences in regional income and labor productivity are associated with productivity of public capital stocks and allocation of private capital stocks. As discussed above, regional data on public and private stocks are not available at all. The data on public capital stocks is available only at national level and the data on private capital stocks are available at national sectoral level. Given such data constraints, we have devised a method, which could help in explaining the regional disparity.

The specified regional aggregate and regional sectoral production functions with three inputs, respectively, are shown in (1) and (2).

Regional aggregate production function:

$$
Y_{r t}=B G_{t}^{\alpha_{r}} L_{r t}^{\beta_{r} \ln b_{r} K_{t}} \quad r(\text { region })=1,2
$$

and it's statistical form is:

\footnotetext{
${ }^{2}$ We also calculated disparity measures for sectoral per capita income, labor productivity and employment ratio respectively. Among the regions disparity in per capita income and labor productivity is highest in manufacturing sector and lowest in agriculture sector while disparity in employment ratio is relatively high in manufacturing, services and trade sectors.

${ }^{3}$ Since the study intends to analyze the role of public capital stocks at regional sectoral level in Pakistan's economy, we adopted the following sectoral classification for the analysis: 1. Agriculture sector including fishing, forestry, hunting and animal husbandry; 2. Manufacturing sector including mining and quarry; 3. Energy sector including gas and electricity; 4. Construction sector; 5. Transport and communication sector including storage; 6. Wholesale and retail trade sector; and 7. Services sector including finance, insurance, real estate and community services.

${ }^{4}$ Refer to Khan and Sasaki (2001) for detailed method pertaining to construction of capital stock series and refer to Khan (2001) for the series of data used in analysis and regional data problems.
} 


$$
\begin{aligned}
& \ln Y_{r t}=\ln B+\alpha_{r} \ln G_{t}+\beta_{r} \ln b_{r} K_{t} \ln L_{r t}+\gamma_{r} D_{r} \\
& \alpha_{r}>0, \quad \beta_{r}>0 \quad \text { and, } \quad D_{r}= \begin{cases}0 & \text { for } 1972-1980 \\
1 & \text { otherwise }\end{cases}
\end{aligned}
$$

and

Regional sectoral production function:

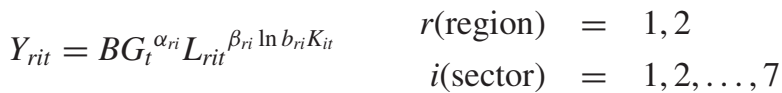

and it's statistical form is:

$$
\begin{aligned}
& \ln Y_{r i t}=\ln B+\alpha_{r i} \ln G_{t}+\beta_{r i} \ln b_{r i} K_{i t} \ln L_{r i t} \\
& \alpha_{r i}>0, \quad \beta_{r i}>0
\end{aligned}
$$

where,

$Y_{r t}, Y_{r i t}=$ real values added at regional aggregate level and regional sectoral level $i$ at time $t$, respectively.

$L_{r t}, L_{r i t}=$ employed labors in region $r$ and in region's sector $i$ at time $t$, respectively.

$K_{t}, K_{i t}=$ aggregate private capital stocks in the national economy and sector $i$, respectively.

$D_{r}=$ dummy variable for periods and regions indicating the availability of public capital across the regions (before 1980, public capital, hypothesized, to be not available across the regions).

$G_{t}=$ aggregate public capital stock in the national economy at time $t$.

$b_{r}, b_{r i}=$ unknown average shares of private capital stocks allocated to region $r$ and region's sector $i$, respectively.

The basic assumption in the specified production functions (1) and (2) is that the services from the public capital stocks are equally available to both regions, without reference to allocation pattern. ${ }^{(5)}$ And the efficiency of labor in each region and in each sector depends on the private capital stocks allocated to that region. Letting the average shares of private capital stocks allocated to Region 1 and 2 are denoted by $b_{r}$ and $1-b_{r}$, respectively, the private capital stocks allocated to each region are estimated as $b_{r} K_{t}$ and $\left(1-b_{r}\right) K_{t}$, respectively. Since regional private capital stocks are not available, the average share of private capital stock $b_{r}$, is also unknown and to be estimated. ${ }^{(6)}$ Further, it is also hypothesized that the efficiencies of public and private capital stocks are different between two regions, which are reflected in the values of $\alpha_{r}$ and $\beta_{r}$.

For the subsequent empirical analyses time series data for the period of 1972-97 was used. We estimated the regional production functions both at aggregate and sector level for each region with a pre-assigned value of $b_{r}$. The production functions were estimated by changing the value of $b$ by 0.05 from 0.95 to 0.05 : this implies that totally twenty regressions were estimated for each specification in each region. The estimation results were compared among twenty pairs of regressions for the two regions, and then the assigned values of $b_{r}$ and $\left(1-b_{r}\right)$ associated with the best pair (that brought about the highest goodness-of-fit under the significant regression coefficients) were taken as the estimates of $b_{r}$ and $\left(1-b_{r}\right)$. On the basis of the estimate of $b_{r}$, we could find how much average share of private capital stocks has been allocated to each region. Beside the aggregate public capital, it's different components are also used in the separate estimations, where " $G$ represents for aggregate public capital stock, $G_{1}$ : irrigation, dams and other agriculturerelated public capital, $G_{2}$ : roads, highways and other transportation and communication and $G_{3}$ : financial sector facilities provided by the government". Results of estimation of Eq. (1) are reported in Table 4.

The best results cited in the above Table indicate that the average shares of the allocated private capital are $90 \%$ to Region 1 and $10 \%$ to Region 2, when aggregate public capital stock $G$ is used in the estimation. The coefficient of public capital stocks $\alpha_{r}$ i.e., the productivity of public stock is positive and statistically significant at a $1 \%$ level in both regions and the comparison of size of $\alpha_{r}$ indicates that public capital stock are more efficiently used in Region 1 than Region 2. The labor efficiency coefficients $\beta_{r}$ are positive and significant at $1 \%$ level, in both regions. The size of $\beta_{r}$ in Region 2 is grater than the one in Region 1, indicating that the allocated share of private capital is used more efficiently in Region 2 than in Region 1 so as to heighten the efficiency of labor input in that region. The coefficients of dummy variable $\gamma_{r}$ are positive and significant at $1 \%$ level in both regions, indicating/confirming that where public capital is available across the regions, it is used more efficiently.

${ }^{5}$ Due to non-availability of regional public capital stock data we relied on the assumption that services from the public capital stocks are equally available to all regions, although this assumption does not represent entire reality but in the case of road, highways as well as network communication the regions can use and benefit from the same public facilities.

${ }^{6}$ We appreciate the suggestions of an anonymous referee for trying more direct estimation method; as

$$
\begin{aligned}
& \qquad \begin{aligned}
\ln Y_{r t} & =\ln B+\alpha_{r} \ln G_{t}+\beta_{r}\left(\ln b_{r}+\ln K_{t}\right) \ln L_{r t} \\
& =\alpha_{0}+\alpha_{r} \ln G_{t}+\beta_{r} \ln L_{r t}+\beta_{r} \ln K_{t} \ln L_{r t} \\
& =\alpha_{0}+\alpha_{r} \ln G_{t}+C_{r} \ln L_{r t}+\beta_{r} \ln K_{t} \ln L_{r t}
\end{aligned} \\
& \text { where } C_{r}=\beta_{r} \ln b_{r} \quad \text { and } \quad b_{r}=\exp \left(\frac{C_{r}}{\beta_{r}}\right)
\end{aligned}
$$

We already tried that method as well, and the problem with this method is that the restriction on the parameter $b_{r}$ that is, the average share of private capital between two regions must be unity, does not hold. 
Table 4. Results of aggregate regional production functions.

\begin{tabular}{|c|c|c|c|c|c|c|c|}
\hline Region & $\begin{array}{c}\text { Equation/ } \\
\text { Description of } \\
\text { public capital }\end{array}$ & $\begin{array}{c}\text { Average share } \\
\text { of private capital } \\
\qquad\left(b_{r}\right)\end{array}$ & $\begin{array}{l}\text { Constant } \\
\text { (B) }\end{array}$ & $\begin{array}{l}\ln G_{t} \\
\left(\alpha_{r}\right)\end{array}$ & $\begin{array}{c}\ln b_{r} K_{t} \ln L_{r t} \\
\left(\beta_{r}\right)\end{array}$ & $\begin{array}{c}D_{r} \\
\left(\gamma_{r}\right)\end{array}$ & $\bar{R}^{2}$ \\
\hline Region 1 & $(1-1) \mathrm{G}$ & 0.90 & $\begin{array}{c}3.135 \\
(10.413)^{* *}\end{array}$ & $\begin{array}{c}0.356 \\
(7.655)^{* * *}\end{array}$ & $\begin{array}{c}0.023 \\
(14.546)^{* *}\end{array}$ & $\begin{array}{c}0.078 \\
(4.021)^{\text {*** }}\end{array}$ & 0.996 \\
\hline Region 2 & $(1-2) \mathrm{G}$ & 0.10 & $\begin{array}{c}1.746 \\
(4.967)^{* *}\end{array}$ & $\begin{array}{c}0.166 \\
(2.750)^{\text {*** }}\end{array}$ & $\begin{array}{c}0.045 \\
(14.173)^{* *}\end{array}$ & $\begin{array}{c}0.048 \\
(2.098)^{\text {*** }}\end{array}$ & 0.995 \\
\hline Region 1 & $(1-3) G_{2}$ & 0.95 & $\begin{array}{c}4.186 \\
(20.629)^{* *}\end{array}$ & $\begin{array}{c}0.256 \\
(7.204)^{* * *}\end{array}$ & $\begin{array}{c}0.025 \\
(15.945)^{* *}\end{array}$ & $\begin{array}{c}0.0793 \\
(3.889)^{\text {*** }}\end{array}$ & 0.993 \\
\hline Region 2 & $(1-4) \mathrm{G}_{2}$ & 0.05 & $\begin{array}{c}2.706 \\
(11.431)^{* *}\end{array}$ & $\begin{array}{c}0.126 \\
(2.915)^{\text {*** }}\end{array}$ & $\begin{array}{c}0.0458 \\
(15.812)^{* *}\end{array}$ & $\begin{array}{c}0.0515 \\
(2.184)^{* * *}\end{array}$ & 0.995 \\
\hline Region 1 & $(1-5) \mathrm{G}_{3}$ & 0.90 & $\begin{array}{c}4.287 \\
(30.902)^{* *}\end{array}$ & $\begin{array}{c}0.275 \\
(10.821)^{* * *}\end{array}$ & $\begin{array}{c}0.026 \\
(28.288)^{* * *}\end{array}$ & $\begin{array}{c}0.0561 \\
(3.563)^{* * *}\end{array}$ & 0.998 \\
\hline Region 2 & $(1-6) \mathrm{G}_{3}$ & 0.10 & $\begin{array}{c}2.230 \\
(10.722)^{* *}\end{array}$ & $\begin{array}{c}0.141 \\
(3.542)^{\text {*** }}\end{array}$ & $\begin{array}{c}0.046 \\
(21.048)^{* * *}\end{array}$ & $\begin{array}{c}0.0325 \\
(1.905)\end{array}$ & 0.995 \\
\hline
\end{tabular}

Equations (1-3) and (1-4) show the estimates of regional production functions using $\left(G_{2}\right)$ component of public capital. The best estimation results show that the average shares of the allocated private capital are $95 \%$ to Region 1 and 5\% to Region 2. The coefficients $\alpha_{r}$ are positive in both regions and statistically significant at a $1 \%$ level in both the regions and the comparison of size of $\alpha_{r}$ indicates that the $G_{2}$ component of public capital stock are more efficiently used in Region 1 than Region 2. The coefficients $\beta_{r}$ are positive and significant in both regions at $1 \%$ level, respectively. The size of $\beta_{r}$ in Region 2 is larger than the one in Region 1. Similarly the coefficients of dummy variable are positive and significant at $1 \%$ level in both regions. Equations (1-5) and (1-6) show the estimates using $\left(G_{3}\right)$ component of public capital. The best estimation results in this case show that the average shares of private capital allocated are 90\% in Region 1 and 10\% in Region 2. In this case also the coefficients $\alpha_{r}$ and $\beta_{r}$ are positive and statistically significant at a $1 \%$ level in both regions. The coefficient of dummy variable $\gamma_{r}$ are positive in both regions and statistically significant at a $1 \%$ level in Region 1 where as at a 5\% level in Region 2 . The coefficient of determination adjusted for degree of freedom $\left(\bar{R}^{2}\right)$ is high in all three cases.

To sum up, the comparison of the coefficients $\alpha_{r}$ in two regions indicates that aggregate public capital stocks as well as it's two different components have positive and much stronger/significant impact on the output of the relatively advanced region comparing the relatively backward region. The comparison of coefficients $\beta_{r}$ between two regions indicates that the private capital is used more efficiently in relatively backward region than in the advanced region, in either case using aggregate or components of public capital in the estimation. An interpretation is that the share of private capital allocated to backward region is very small (around $10 \%$ of total private capital) and thus private capital is scarce so it is used more efficiently in that region. As a result, the labor efficiency is promoted more in relatively backward region than in advanced region. Furthermore, the estimated $\gamma_{r}$ indicates that where the public capital is available across the regions, that is, there is no hindrance in the use of same public facility by the regions (especially the transport network, highways and motorway, communication facilities), public capital is used more efficiently.

It should be noted that we adopted a specific functional form of the production functions, with variable elasticity of substitution, so the parameters $\beta_{r}$ in two regions cannot directly be referred to as output elasticity of labor or private capital stocks. ${ }^{(7)}$ We thus, calculated output elasticity of labor and private capital for Eqs. (1-1) through (1-6) at the average values of each variable. Table 5 shows the output elasticities of public capital, labor and private capital inputs for comparison.

This result shows that public capital is more efficiently used and plays a much stronger/significant role in the production process of Region 1 than Region 2. A possible reason is that there are less economic activities and

Table 5. Output elasticity estimates of regional production functions.

\begin{tabular}{|c|c|c|c|c|c|c|}
\hline \multirow{2}{*}{\begin{tabular}{|r|} 
Region \\
Elasticity
\end{tabular}} & \multicolumn{3}{|c|}{ Region 1} & \multicolumn{3}{|c|}{ Region 2} \\
\hline & $\varepsilon_{\mathrm{G}}$ & $\varepsilon_{L}$ & $\varepsilon_{\mathrm{K}}$ & $\varepsilon_{\mathrm{G}}$ & $\varepsilon_{\mathrm{L}}$ & $\varepsilon_{\mathrm{K}}$ \\
\hline G & 0.357 & 0.302 & 0.404 & 0.166 & 0.477 & 0.692 \\
\hline G2 & 0.256 & 0.320 & 0.425 & 0.127 & 0.449 & 0.697 \\
\hline G3 & 0.276 & 0.341 & 0.454 & 0.141 & 0.493 & 0.715 \\
\hline
\end{tabular}

\footnotetext{
${ }^{7}$ Output elasticities of labor and private capital inputs are defined as:

$$
\begin{aligned}
\varepsilon_{L} & =\partial \ln Y / \partial \ln L=\hat{\beta} \ln b \bar{K} \\
\varepsilon_{K} & =\partial \ln Y / \partial \ln b K=\hat{\beta} \ln \bar{L}
\end{aligned}
$$
}

where $\bar{L}$ and $\bar{K}$ are average labor and private capital stock respectively. 
Table 6. Output elasticity estimates at regional sectoral level.

\begin{tabular}{|l|cccccc|}
\hline \multirow{2}{*}{ Rector/Elasticity } & \multicolumn{3}{c}{ Region 1 } & \multicolumn{3}{c|}{ Region 2 } \\
\cline { 2 - 7 } & $\varepsilon_{\mathrm{G}}$ & $\varepsilon_{\mathrm{L}}$ & $\varepsilon_{\mathrm{K}}$ & $\varepsilon_{\mathrm{G}}$ & $\varepsilon_{\mathrm{L}}$ & $\varepsilon_{\mathrm{K}}$ \\
\hline Agriculture & 0.527 & 0.079 & 0.066 & 0.428 & 0.236 & 0.206 \\
Manufacturing & 0.428 & 0.567 & 0.390 & 0.953 & 0.058 & 0.041 \\
Construction & 0.615 & 0.085 & 0.067 & 0.681 & 0.073 & 0.060 \\
Energy & 1.385 & 0.061 & 0.036 & 2.369 & 0.029 & 0.015 \\
Transport \& Com & 0.722 & 0.295 & 0.202 & 0.894 & 0.114 & 0.084 \\
Trade & 0.506 & 0.290 & 0.266 & 0.074 & 0.367 & 0.360 \\
Services & 0.414 & 0.438 & 0.297 & 0.311 & 0.435 & 0.304 \\
\hline
\end{tabular}

opportunities in Region 2 for using the public capital efficiently and effectively. Output elasticities with respect to labor input, when aggregate public capital is used in the estimation, indicate that contribution of labor to output is much higher in Region 2 than in Region 1. Similarly output elasticity with respect to private capital shows that private capital contributes more in production process in Region 2 than in Region 1.

Output elasticities with respect to public capital $G_{2}$ and $G_{3}$ are 0.25 and 0.27 in Region 1 and 0.12 and 0.14 in Region 2, respectively. Output elasticities with respect to labor and private capital input are much higher for Region 2 than for Region 1, and these values are rather robust regardless of different components of public capital.

At regional sectoral level we estimated Eq. (2), and results are reported in Table A.1 in the Appendix. ${ }^{(8)}$ The average share of private capital in Region 1 is estimated to be $95 \%$ in manufacturing and transport sectors, $90 \%$ in agriculture, construction, trade and services, and $80 \%$ in energy sector. In all most all cases the aggregate public capital or its components have positive and significant contribution in the production process of both regions' sectors.

Output elasticity estimates with respect to the inputs for each sector in both regions are reported in Table 6 .

In agriculture and trade sectors the output elasticities with respect to labor and private capital are larger in Region 2 while in manufacturing, energy and transport sectors output elasticites with respect to labor and private capital are larger in Region 1. In case of construction and services sectors these elasticities do not differ much between the two regions. Furthermore, it is possible to give an interpretation that private capital is used more efficiently to heighten the labor productivity in manufacturing and transport sectors in relatively advanced region while in agriculture and trade sectors, in backward region. In case of construction and services sectors, the efficiency in the use of private capital is more or less the same in both regions. The differences in elasticity indicate that production technology may differ between the regions.

\subsection{Test of technological difference in production}

To test whether the production functions in the two regions are identical or not, the Chow test is applied. In the specification of production function in (1) and (2), the null hypothesis is:

and

$$
B_{1}=B_{2}, \quad \alpha_{1}=\alpha_{2}, \quad \beta_{1}=\beta_{2} \quad \text { and }, \quad \gamma_{1}=\gamma_{2}
$$

$$
B_{1 i}=B_{2 i} \quad \alpha_{1 i}=\alpha_{2 i}, \quad \text { and } \quad \beta_{1 i}=\beta_{2 i},
$$

respectively.

The alternative hypothesis is:

and

$$
B_{1} \neq B_{2}, \quad \alpha_{1} \neq \alpha_{2}, \quad \beta_{1} \neq \beta_{2} \quad \text { and }, \quad \gamma_{1} \neq \gamma_{2}
$$

$$
B_{1 i} \neq B_{2 i}, \quad \alpha_{1 i} \neq \alpha_{2 i}, \quad \text { and } \quad \beta_{1 i} \neq \beta_{2 i},
$$

respectively.

F- values for the Chow test are reported in Table 7. It is evident that F-values are highly significant in all cases, regional aggregate as well as at regional sectoral level. It is therefore concluded that the production technologies are different between two regions.

The difference in production technology may be one of important causes of the regional income and regional labor productivity differences observed above. It is needed to investigate which coefficient in production functions differs more largely between the two regions. For this purposes the Dummy variable method is used and the following equations were estimated.

\footnotetext{
${ }^{8}$ We tried to use dummy variables for periods and regions in the regional sectoral production functions as well, but the either the sign conditions of parameters were not met or results were insignificant in most cases.
} 
Table 7. Test of technological difference.

\begin{tabular}{c|c|c}
\hline Region/Sector & Public capital & F-value \\
\hline Regional level & $\mathrm{G}$ & $52.13^{* *}$ \\
Regional level & $\mathrm{G}_{2}$ & $30.97^{* *}$ \\
Regional level & $\mathrm{G}_{3}$ & $51.48^{* *}$ \\
Sector-1 & $\mathrm{G}_{1}$ & $20.20^{* *}$ \\
Sector-2 & $\mathrm{G}$ & $05.32^{* *}$ \\
Sector-2 & $\mathrm{G}_{2}$ & $03.49^{*}$ \\
Sector-3 & $\mathrm{G}_{3}$ & $33.76^{* *}$ \\
Sector-4 & $\mathrm{G}$ & $21.64^{* *}$ \\
Sector-5 & $\mathrm{G}_{2}$ & $10.34^{* *}$ \\
Sector-6 & $\mathrm{G}_{3}$ & $23.98^{* *}$ \\
Sector-7 & $\mathrm{G}_{3}$ & $10.26^{* *}$ \\
\hline ** significant at a 1\% level & significant at a 5\% level &
\end{tabular}

Table 8. Results of dummy variable test at regional level.

\begin{tabular}{|c|c|c|c|c|c|c|c|c|}
\hline nn. & $B_{2}$ & $\left(B_{1}-B_{2}\right)$ & $\alpha_{2}$ & $\left(\alpha_{1}-\alpha_{2}\right)$ & $\beta_{2}$ & $\left(\beta_{1}-\beta_{2}\right)$ & $\gamma_{2}$ & $\left(\gamma_{1}-\gamma_{2}\right)$ \\
\hline$(3-1) \mathrm{G}$ & $\begin{array}{l}1.746 \\
(5.43)^{* * *}\end{array}$ & $\begin{array}{c}1.388 \\
(2.98)^{* * *}\end{array}$ & $\begin{array}{c}0.166 \\
(3.00)^{* * *}\end{array}$ & $\begin{array}{c}0.190 \\
(2.51)^{* *}\end{array}$ & $\begin{array}{c}0.045 \\
(15.48)^{* *}\end{array}$ & $\begin{array}{l}-0.021 \\
(-6.24)^{* *}\end{array}$ & $\begin{array}{l}0.048 \\
(2.29)^{* *}\end{array}$ & $\begin{array}{c}-0.029 \\
(0.97)\end{array}$ \\
\hline (3-2) $\mathrm{G}_{2}$ & $\begin{array}{c}2.706 \\
(12.29)^{* *}\end{array}$ & $\begin{array}{c}1.479 \\
(4.74)^{* * *}\end{array}$ & $\begin{array}{c}0.126 \\
(3.14)^{* * *}\end{array}$ & $\begin{array}{c}0.129 \\
(2.31)^{* * *}\end{array}$ & $\begin{array}{c}0.045 \\
(17.01)^{* * *}\end{array}$ & $\begin{array}{c}-0.021 \\
(-6.47)^{* *}\end{array}$ & $\begin{array}{c}0.051 \\
(2.35)^{* *}\end{array}$ & $\begin{array}{l}0.028 \\
(0.89)\end{array}$ \\
\hline (3-3) $G_{3}$ & $\begin{array}{l}2.230 \\
(12.55)^{* *}\end{array}$ & $\begin{array}{l}2.056 \\
(8.25)^{* *}\end{array}$ & $\begin{array}{c}0.141 \\
(4.15)^{* * *}\end{array}$ & $\begin{array}{c}0.134 \\
(2.88)^{* *}\end{array}$ & $\begin{array}{l}0.046 \\
\left(24.65^{* *}\right.\end{array}$ & $\begin{array}{l}-0.020 \\
(-8.93)^{* *}\end{array}$ & $\begin{array}{c}0.032 \\
(1.65)^{*}\end{array}$ & $\begin{array}{l}0.023 \\
(0.84)\end{array}$ \\
\hline
\end{tabular}

*** significant at a $1 \%$ level $\quad$ * significant at a $10 \%$ level

$$
\begin{aligned}
\ln y_{r}= & B_{2}+\left(B_{1}-B_{2}\right) D_{1}+\alpha_{2} \ln G+\left(\alpha_{1}-\alpha_{2}\right)\left(D_{2} \ln G\right)+\beta_{2} \ln b_{r} K_{r} \ln L_{r} \\
& +\left(\beta_{1}-\beta_{2}\right)\left(D_{3} \ln b_{r} K_{r} \ln L_{r}+\gamma_{2}+\left(\gamma_{1}-\gamma_{2}\right) D_{4}+u_{r}\right. \\
\ln y_{r i}= & B_{2 i}+\left(B_{1 i}-B_{2 i}\right) D_{1 i}+\alpha_{2 i} \ln G+\left(\alpha_{1 i}-\alpha_{2 i}\right)\left(D_{2 i} \ln G\right)+\beta_{2 i} \ln b_{r i} K_{r i} \ln L_{r i} \\
& +\left(\beta_{1 i}-\beta_{2 i}\right)\left(D_{3 i} \ln b_{r i} K_{r i} \ln L_{r i}\right)+u_{r i}
\end{aligned}
$$

in which,

$$
\begin{array}{ll}
D_{1}=D_{2}=D_{3}=D_{4}=1, & \text { where } r=1 \\
D_{1}=D_{2}=D_{3}=D_{4}=0, & \text { where } r=2
\end{array}
$$

That is, the effect of dummy variable measures to what extent the coefficients of production function in Region 1 differs from those in Region 2.

Table 8 shows the estimated results of Eq. (3). Equations (3-1) (3-2) and (3-3) show the estimation results when aggregate as well as components of public capital are used in the estimation, respectively. The coefficient of D1 is statistically significant at a 1\% level in cases of (3-1), (3-2) and (3-3) respectively, suggesting that the level of technology is different in two regions. Since the coefficient of $D_{1}$ is significantly positive, it follows that Region 1 has superior production technology than the Region 2. The coefficients of $D_{2}$ are positive and significant at $1 \%$ level in all three equations. This result indicates that the efficiency of public capital is significantly different in two regions, that is $\alpha_{1}>\alpha_{2}$, and thus, suggests that public capital is used more efficiently in advanced region. Similarly the coefficients of $D_{3}$ in all three cases are negative and statistically significant at $1 \%$ level respectively, indicating that the effect of private capital to heighten the efficiency of labor input is lager for the Region 2 than for Region 1 , that is, $\beta_{1}>\beta_{2}$. Although the coefficient of $D_{4}$ is negative in the case of (3-1) and positive in the cases of (3-2) and (3-3), but statistically insignificant in all three cases, indicating the effect of dummy is same in both regions, that is, the effect of across region availability of public capital is equal between two regions (i.e., $\gamma_{1}=\gamma_{2}$ ).

Table 9 shows the estimation results of Dummy variable model for each sector. The comparison of coefficients of $D_{1 i}$ in each sector indicates that, in agriculture and services sectors the coefficients are insignificant. Therefore, we do not reject the null hypothesis of equal production technology level between two regions. In most of other sectors the coefficients of $D_{1 i}$ are significant at $1 \%$ level, indicating difference of production technology between the two regions.

The coefficients of $D_{2 i}$ are statistically not significant in agriculture, construction, transport and services sectors, 
Table 9. Results of dummy variable test at regional-sectoral level.

\begin{tabular}{|c|c|c|c|c|c|c|c|}
\hline Sector & Eqns. & $B_{2 i}$ & $\left(B_{1 i}-B_{2 i}\right)$ & $\alpha_{2 i}$ & $\left(\alpha_{1 i}-\alpha_{2 i}\right)$ & $\beta_{2 i}$ & $\left(\beta_{1 i}-\beta_{2 i}\right)$ \\
\hline Sector-1 & $(4-1) \mathrm{G}_{1}$ & $\begin{array}{c}4.018 \\
(2.262)^{*}\end{array}$ & $\begin{array}{c}1.847 \\
(1.281)\end{array}$ & $\begin{array}{c}0.427 \\
(0.970)\end{array}$ & $\begin{array}{c}0.106 \\
(0.875)\end{array}$ & $\begin{array}{c}0.026 \\
(9.603)^{* *}\end{array}$ & $\begin{array}{c}-0.019 \\
(-2.210)^{*}\end{array}$ \\
\hline Sector-2 & $(4-2) \mathrm{G}_{2}$ & $\begin{array}{c}-2.833 \\
(-2.163)^{*}\end{array}$ & $\begin{array}{c}4.309 \\
(2.950)^{* *}\end{array}$ & $\begin{array}{c}0.935 \\
(4.229)^{* *}\end{array}$ & $\begin{array}{c}-0.507 \\
(-1.981)^{*}\end{array}$ & $\begin{array}{c}0.008 \\
(0.338)\end{array}$ & $\begin{array}{c}0.041 \\
(1.413)\end{array}$ \\
\hline Sector-3 & $(4-3) G_{3}$ & $\begin{array}{c}1.138 \\
(1.637)\end{array}$ & $\begin{array}{c}1.924 \\
(2.006)^{*}\end{array}$ & $\begin{array}{c}0.683 \\
(6.561)^{* * *}\end{array}$ & $\begin{array}{c}-0.065 \\
(-0.442)\end{array}$ & $\begin{array}{c}0.010 \\
(1.048)\end{array}$ & $\begin{array}{c}-0.001 \\
(-0.095)\end{array}$ \\
\hline Sector-4 & $(4-4) \mathrm{G}$ & $\begin{array}{c}-21.620 \\
(-14.28)^{* * *}\end{array}$ & $\begin{array}{c}12.882 \\
(6.305)^{* *}\end{array}$ & $\begin{array}{c}2.369 \\
(17.104)^{* * *}\end{array}$ & $\begin{array}{c}-0.984 \\
(-5.260)^{* * *}\end{array}$ & $\begin{array}{c}0.004 \\
(0.277)\end{array}$ & $\begin{array}{c}0.003 \\
(0.167)\end{array}$ \\
\hline Sector-5 & $(4-5) G_{2}$ & $\begin{array}{c}-5.090 \\
(-3.890)^{* *}\end{array}$ & $\begin{array}{c}4.180 \\
(2.945)^{* *}\end{array}$ & $\begin{array}{c}0.980 \\
(3.546)^{* *}\end{array}$ & $\begin{array}{c}-0.256 \\
(-0.859)\end{array}$ & $\begin{array}{c}0.039 \\
(0.791)\end{array}$ & $\begin{array}{c}-0.003 \\
(-0.063)\end{array}$ \\
\hline Sector-6 & $(4-6) \mathrm{G}_{3}$ & $\begin{array}{c}6.549 \\
(27.11)^{* *}\end{array}$ & $\begin{array}{c}-2.765 \\
(-7.806)^{* *}\end{array}$ & $\begin{array}{c}0.076 \\
(1.969)^{*}\end{array}$ & $\begin{array}{c}0.430 \\
(7.442)^{\text {*** }}\end{array}$ & $\begin{array}{c}0.057 \\
(14.233)^{* * *}\end{array}$ & $\begin{array}{c}-0.023 \\
(-4.789)^{\text {*** }}\end{array}$ \\
\hline Sector-7 & $(4-7) \mathrm{G}_{3}$ & $\begin{array}{c}3.185 \\
(11.13)^{* *}\end{array}$ & $\begin{array}{c}0.292 \\
(0.758)\end{array}$ & $\begin{array}{c}0.337 \\
(5.439)^{* * *}\end{array}$ & $\begin{array}{c}0.078 \\
(0.934)\end{array}$ & $\begin{array}{c}0.045 \\
(7.233)^{* *}\end{array}$ & $\begin{array}{c}-0.008 \\
(-1.088)\end{array}$ \\
\hline
\end{tabular}

suggesting that the efficiency of public capital in these sectors is equal in the two regions. In manufacturing, energy and trade sectors the coefficients of $D_{2 i}$ are statistically significant at $1 \%$ and $5 \%$ respectively, indicating the efficiency of public capital differs in these sectors between the regions.

The coefficients of $D_{3 i}$ in agriculture and trade sectors are negative and significant at 5\% and $1 \%$ level respectively, suggesting that the effect of private capital in these sectors is higher for the Region 2 than for the Region 1, that is, $\beta_{2 i}>\beta_{1 i}$. In all other sectors the coefficients of $D_{3 i}$ are statistically insignificant, and we can conclude that the efficiency of labor is equal between the two regions in those sectors. ${ }^{(9)}$

\section{Regional Population and Labor}

For regional population ratio we specified and tested several hypotheses but the results revealed that differences in income and growth rate of employment can not explain the migration behavior in Pakistan. As mentioned before, several studies in Pakistan, for example Ahmed and Sirageldin (1993) and Perveen (1993) found that migration in Pakistan is selective in terms of age and education, and are generally influenced by the job opportunities at the destination. Furthermore, factors like social customs, ethnic differences and cultural and tribal bondages work as restrain to mass migration. We thus finally, adopted the regional population function for the Region 1 as shown in Eq. (5), which is based on inertia hypothesis: that is, population in Region 1 depends on previous state. Job opportunity is proxied by the relative employment ratio between two regions in the previous year.

$$
\begin{aligned}
& \ln \left(\frac{P O P_{1 t}}{N P O P_{t}}\right)=-0.019+0.920 \ln \left(\frac{P O P_{1(t-1)}}{N P O P_{(t-1)}}\right)+0.001 \ln \left(\left(\frac{\frac{L_{1}}{P O P_{1}}}{\frac{L_{2}}{P O P_{2}}}\right)_{t-1}\right) \\
& (-2.391) \quad(26.423) \\
& \bar{R}^{2}=0.974
\end{aligned}
$$

Equation (5) shows the coefficient of inertia is positive and significant at a $1 \%$ level indicating population ratio in Region 1 is gradually changing over the time. The coefficient of job opportunity variable is positive and significant at a $5 \%$ level, indicating that relatively higher jobs opportunities in Region 1 give incentive to people to migrate from Region 2. Our findings are consistent with the evidence from earlier studies on Pakistan and other developing countries, as mentioned above.

\section{Labor employment:}

Labor employment ratio function is specified as given in Eq. (6) where labor productivity in a region is used as a proxy for regional wage rate. ${ }^{(10)}$

\footnotetext{
${ }^{9}$ In order to determine the private capital stock at $t, K_{t}$ (or $K_{i t}$ ), the investment behavior of private sector/firms in Pakistan needs to be analyzed. And we already did it in Khan and Sasaki [2001, Section 4].

${ }^{10}$ Although we also tried several specifications for the labor function including the use of dummy for periods and regions but the results were not satisfactory.
} 


$$
\begin{aligned}
& \ln \left(\frac{L_{1}}{P O P_{1}}\right)=-1.0485+0.3749 \ln \left(\frac{L_{1}}{P O P_{1}}\right)_{t-1}+0.0315 \ln \left(\frac{G D P_{1}}{L_{1}}\right)_{t-1} \\
& (-2.834) \\
& \bar{R}^{2}=0.838
\end{aligned}
$$

\section{Regional sectoral labor allocation:}

Regional sectoral labor allocation function for each sector is specified as shown in Eq. (7), where labor productivity in a region's sector relative to national labor productivity is used as proxy for regional sectoral wage rate. Estimation results for each sector in Region 1 are reported in Table A.2 of the Appendix.

$$
\ln \left(\frac{L_{r i}}{L_{r}}\right)=\alpha+\beta \ln \left(\frac{L_{r i}}{L_{r}}\right)_{t-1}+\gamma \ln \left(\left(\frac{\frac{G D P_{r i}}{L_{r i}}}{\frac{G D P}{L}}\right)_{t-1}\right) \begin{array}{r}
r(\text { region })=1,2 \\
i(\text { sector })=1,2, \ldots, 7 .
\end{array}
$$

\section{System of Regional Econometric Model}

We attempted to construct a regional econometric model based on our estimated regional production, regional population and labor relations and investment functions. The model aimed at both explaining the structure of regional economy of Pakistan, and helping to evaluate various government policies, especially the public investment policies, for reducing regional disparity among the regions.

Flowchart in Fig. 2 represents the main blocks and their interactions in the Pakistan's regional econometric model. Given the national population, public investment and bank credit to private sectors, the national sectoral investment is determined in the first place, and subsequently national and sectoral private capital stocks are determined. ${ }^{(11)}$ Using the

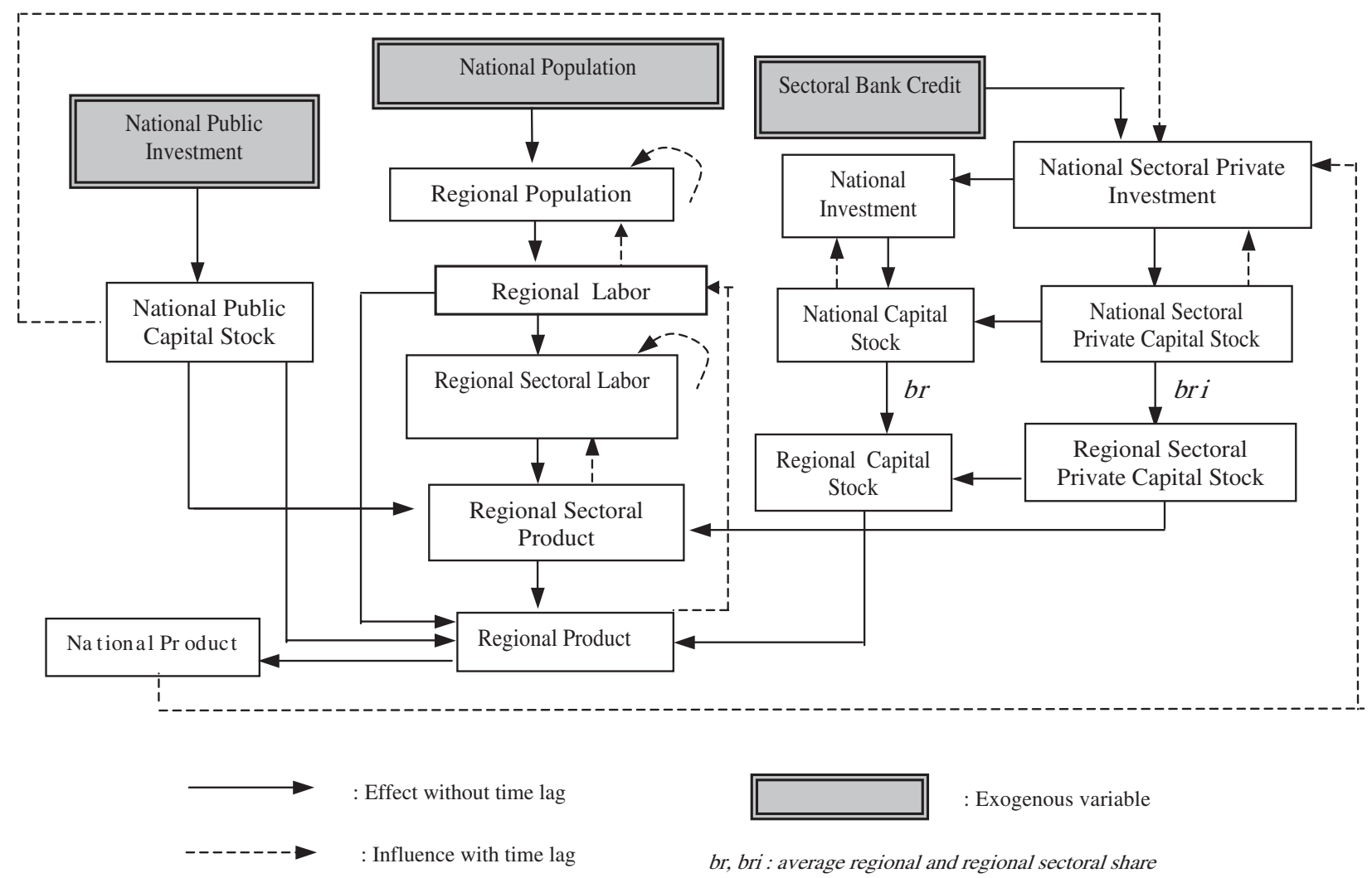

Fig. 2. Flowchart of regional model.

\footnotetext{
${ }^{11}$ he national and sectoral private capital stocks at the end of time $t$ are determined by the following function

$$
\text { National stock formation: } K_{t}=(1-0.064) K_{t-1}+I_{t}
$$$$
\text { Sectoral stock formation: } K_{i t}=\left(1-d_{i}\right) K_{i t-1}+I_{i t}
$$

Where, $d_{i}$ represents the depreciation rate for sector $i$. We used the same flat depreciation rate for entire sample period. Furthermore, in sectors their respective flat depreciation rates are used in the stock functions. 
Table 10. MAPE of national and national sectoral variables (\%).

\begin{tabular}{l|c|c|c}
\hline \multicolumn{1}{c|}{ National/Sector } & & Private capital stock & Private investment \\
\hline National GDP & 02.05 & - & - \\
National Investment & 10.27 & - & - \\
National Private capital & 04.15 & - & - \\
Agriculture & - & 07.6 & 24.4 \\
Manufacturing & - & 23.5 & 34.3 \\
Construction & - & 22.2 & 72.6 \\
Energy & - & 19.2 & 11.1 \\
Transport \& Com. & - & 05.4 & 18.8 \\
Trade & - & 12.7 & 18.4 \\
Services & - & 08.6 & 18.0 \\
\hline
\end{tabular}

Table 11. MAPE of regional and regional sectoral Variables (\%).

\begin{tabular}{l|c|c}
\hline \multicolumn{1}{c|}{ Sector/Region } & Region-1 & Region-2 \\
\hline Regional GDP & 02.8 & 04.7 \\
Regional population & 00.30 & 01.34 \\
Regional labor & 03.36 & 10.36 \\
Regional sectoral GDP & - & - \\
Agriculture & 38.6 & 10.8 \\
Manufacturing & 09.5 & 16.0 \\
Construction & 06.1 & 10.1 \\
Energy & 15.5 & 21.0 \\
Transport \& Com. & 09.4 & 09.8 \\
Trade & 14.3 & 48.4 \\
Services & 06.1 & 04.9 \\
\hline
\end{tabular}

estimates on $b_{r}$ and $b_{r i}$ the regional and regional sectoral private stocks are determined. Combined with regional secotral labor and national public capital stocks they determine regional and regional sectoral output, which is aggregated into national output. The current period's national output will affects next period's national investment and subsequently the regional private capital stock as well as regional labor and regional population. Ultimately in the next period output will be determined by next period's private capital, labor and public capital, and so on.

To evaluate the performance of this econometric model, the final test is carried out to calculate the absolute percentage error for each endogenous variable for the period of 1972-97. Absolute percentage error is defined as follows:

$$
A P E=\frac{\left|\hat{Z}_{t}-Z_{t}\right|}{Z_{t}}
$$

The MAPE (mean absolute percentage error) values for aggregate national and sectoral variables in Table 10 shows that the error associated with national GDP, investment and private capital stock are not so large. The errors associated with national sectoral investment are relatively high, while the error ratios for sectoral private capital stock are relatively low in agriculture, transport, trade and services sectors. The errors associated with aggregate regional and regional sectoral GDP as well as regional population and labor are reported in Table 11, indicating that errors are relatively smaller at aggregate level than the regional sectoral levels, in both regions. Furthermore, the errors associated with regional-sectoral labor are also relatively small for manufacturing, construction, transport and trade sectors in region 1 and construction and transport sectors in region 2, as shown in Table 12. In short, the mean errors of aggregate regional variables are fairly small, while the errors associated with regional sectoral variables are relatively large. With the shortcomings, the adopted structures of the model can be used to analyze various government policies for the regional economy of Pakistan.

\subsection{Simulation analysis}

We have noticed from the regional production analyses that regional private capital level is the most important factor, which determines the level of economic activities in a region and also affects the efficiency of use of public capital and regional income levels, and thereby interregional disparity. The simulation analysis aimed at explaining how the regional disparity and the efficiency of the national economy alter under various scenarios regarding the exogenous variables, namely the level of public capital, changes in bank credit to private sector and the allocated shares 
Table 12. MAPE of regional sectoral labor (\%).

\begin{tabular}{l|c|c}
\hline \multicolumn{1}{c|}{ Sector/Region } & Region-1 & Region-2 \\
\hline Agriculture & 41.77 & 07.89 \\
Manufacturing & 08.93 & 15.46 \\
Construction & 03.46 & 07.00 \\
Energy & 18.40 & 19.43 \\
Transport \& Com. & 04.32 & 03.62 \\
Trade & 05.14 & 61.50 \\
Services & 16.22 & 12.15 \\
\hline
\end{tabular}

Table 13. National GDP (Rupees in billion).

\begin{tabular}{c|cccccccc}
\hline Year & 1973 & 1975 & 1978 & 1982 & 1986 & 1990 & 1995 & 1997 \\
\hline Actual situation & 196 & 217 & 264 & 351 & 438 & 541 & 707 & 783 \\
Scenario-1 & 251 & 283 & 352 & 483 & 615 & 773 & 1027 & 1144 \\
Scenario-2 & 234 & 235 & 274 & 360 & 448 & 552 & 718 & 795 \\
Scenario-3 & 270 & 293 & 358 & 487 & 619 & 777 & 1030 & 1146 \\
Scenario-4 & 196 & 217 & 264 & 351 & 441 & 545 & 711 & 787 \\
\hline
\end{tabular}

of private capital between the regions. The selected scenarios for the simulation are as follows:

Scenario $1\left(S_{1}\right)$ : Increase the level of public capital (double $G$ ), while keeping the average share of private capital to Region $1, b$ to the estimated value (0.9), and Bank credit to private sector as fixed.

Scenario $2\left(\boldsymbol{S}_{2}\right)$ : The level of public capital $(G)$ and Bank credit to private sector are kept fixed, while the average share of private capital allocated to Region $1, b$ is changed to 0.70 .

Scenario $3\left(\boldsymbol{S}_{\mathbf{3}}\right)$ : Increase the level of public capital (double $G$ ) and change $b$ to 0.80 in Region 1, while keeping Bank credit to private sector as fixed.

Scenario $4\left(S_{4}\right)$ : Keeping the level of public capital $(G)$ and the average share of private capital to Region $1, b$, fixed (to 0.9 ) while Bank credit to agriculture sector is increased by $100 \%$.

Results of simulation under alternative scenarios are reported in Table A.3 through A.12 in the Appendix. The comparison of national GDP under alternative cases, as shown in Table 13, for the selected years gives the following order.

\section{Scenario $3>$ Scenario $1>$ Scenario $2>$ Scenario $4>$ Actual situation}

In other words, increase in the level of public capital and changes in the allocated shares of private capital to regions, that is $(b=0.80$ and $1-b=0.20 z$ ), will make more efficient use of public and private capitals in both regions and brings about a large increase in national GDP and per capita incomes of the two regions.

Table 14 shows the level of disparity between two regions, under the alternative scenarios, and the comparison reveals the following sequence.

\section{Scenario $1>$ Scenario $4=$ Actual situation $>$ Scenario $3>$ Scenario $2>$}

Scenario $S_{1}$, increases national GDP to a large extent, but the per capita income disparity between two regions will be also enlarged. Under the given circumstances, Scenario $S_{3}$, will be the best policy to increase national efficiency and to

Table 14. Disparity in per capita income between two regions.

\begin{tabular}{c|cccccccc}
\hline Year & 1973 & 1975 & 1978 & 1982 & 1986 & 1990 & 1995 & 1997 \\
\hline Actual situation & 0.086 & 0.103 & 0.138 & 0.168 & 0.163 & 0.168 & 0.168 & 0.161 \\
Scenario-1 & 0.226 & 0.238 & 0.267 & 0.293 & 0.291 & 0.296 & 0.299 & 0.294 \\
Scenario-2 & 0.381 & 0.232 & 0.137 & 0.090 & 0.089 & 0.082 & 0.079 & 0.085 \\
Scenario-3 & 0.071 & 0.033 & 0.105 & 0.144 & 0.146 & 0.154 & 0.159 & 0.154 \\
Scenario-4 & 0.086 & 0.102 & 0.137 & 0.168 & 0.161 & 0.167 & 0.168 & 0.161 \\
\hline
\end{tabular}


CV versus National GDP (1997)

(Total Public Capital G)

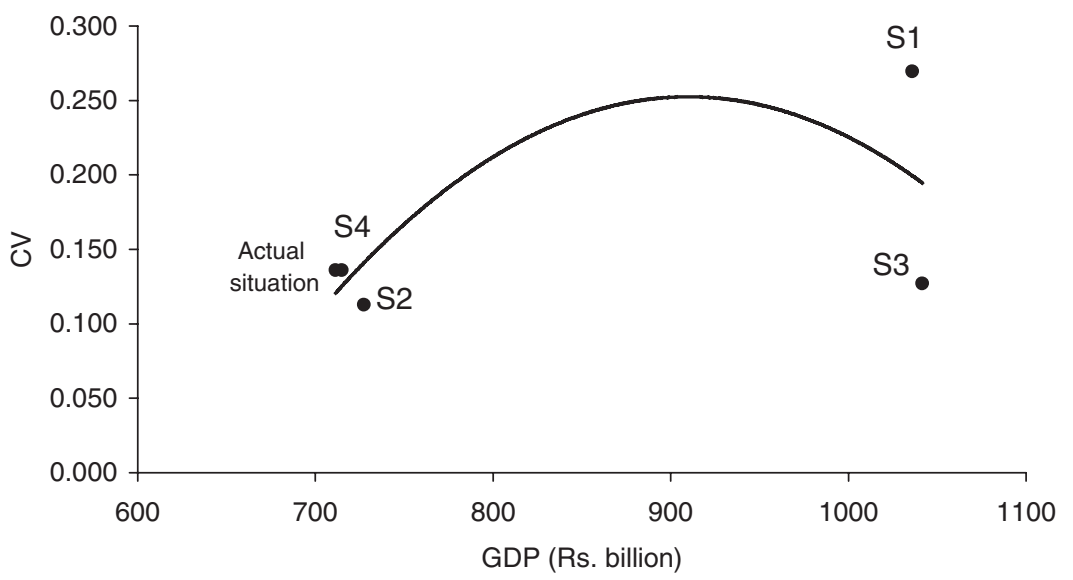

Fig. 3.

reduce the disparity of regional incomes. The comparison of above results indicate that regional disparity and the efficiency of the national economy are strongly affected by changing the allocation patterns of private capital between the regions and the level of public capital in the economy.

Figure 3 shows the relationship between national GDP and the level of disparity for the year 1997, under the alternative scenarios. The comparison of different scenario suggests that the Scenario $S_{3}$, is the superior than other Scenarios in increasing the efficiency of national economy and reducing the income disparities between the regions. Although, the disparity between the regions may enlarge with higher level of economic development until some threshold level, and beyond that development level it will reduce, over the time. The above result also suggests an inverted-U shape relationship between regional disparity and the efficiency of the national economy, which is consistent with the facts and observations in the literature. From the results of the simulation analysis we can conclude that the growth of public capital and the regional allocation patterns of private capital stock between the regions, significantly affects the national as well as regional incomes and consequently the interregional disparity.

There are several policy options which the government can use to encourage private investors to invest in less developed regions. One of such effective policy options is tax holiday for private investors in the less developed regions, for specified period, although that policy in the past has proved to be ineffective. In regional production analysis above, it was confirmed that the level of economic activities in a region largely depends upon the level of development and availability of basic infrastructure. Thus, the result that in the less developed region public capital has relatively weaker role in the production process implies that the less developed region faces insufficient level of basic infrastructure. The basic facilities like water, electricity, transport and communication etc. are prerequisite for productive economic activities. Thus a necessary condition to cure the regional income differences is to provide sufficient basic productive infrastructure in less developed regions. Given the provision of basic productive infrastructure, government policies to attract private investment in the less developed regions with incentives like tax holiday or preferential and subsidized credits, will bring about boost in the level of economic activities and will reduce the economic disparity among regions.

\section{Concluding Remarks}

This study attempted to analyze the role of public capital in regional economies and inter-regional disparity by constructing a regional econometric model for Pakistan. The efficiency of public capital and private inputs has been analyzed by estimating regional production functions at sectoral levels. Finally the efficiency of national economy and the issue of regional disparity have been analyzed. The main findings of the analyses are as follows:

1. The measures of regional disparities show that a sizable disparity in per capita incomes continuously persists among the four regions of Pakistan. The extent of regional disparities in labor productivity and employment ratio are also high and have increasing trend since 1982. In the case of two regions, the disparity in per capita incomes is relatively smaller because of specific distribution of population between the regions.

2. The estimation results of regional production functions show that about $90 \%$ of private capital stocks have been allocated to relatively advanced region and the economic activities are mostly concentrated in that region. Public capital has been contributing significantly in both regions. Nevertheless, it has been more efficiently used in the production process of Region 1 than Region 2. Since a small share of private capital is allocated in region 2, therefore, economic activities are also low and the use of public capital is not as efficient as in the case of 
Region 1. Further, since private capital is scarce in Region 2, it is used more efficiently so as to heighten the labor productivity. In other words, there is potential in Region 2 to grow i.e., increase production and income levels, if a higher share of private capital allocated to that region to stimulate the level of economic activities and make efficient use of public capital.

3. The tests of technological difference show that the two regions utilizes different technologies in their production process, and the difference seems to stem from the allocation of private capital and, as a consequence, from differences in the efficiency of use of public capital between the two regions. The regional production analyses conclude that there is significant difference in production technology, which causes the interregional economic disparity between the regions.

4. The estimation results of regional population functions indicate that relatively higher job opportunities give incentive to people to move from one to another region.

5. The simulation analysis shows that regional disparity and efficiency of the national economy are strongly affected by changing the regional allocation patterns of private capital stocks and the level of public capital. The analysis also suggests an inverted-U shape relationship between regional disparity and the efficiency of the national economy, which is consistent with the ground realities and the observations in the literature.

6. Although the performance of overall model is not very good, especially the error ratios for regional sectoral variables are relatively large. Therefore, the conclusions and policy suggestion should be used with care. In fact the main objective of this study was to explore the ways and devise methods to deal with regional issues, despite severe lacking of required regional data, and in this respect we have achieved the objective.

\section{Acknowledgments}

The authors are grateful for valuable suggestions and useful comments from anonymous referees of the general on the earlier version of the paper. We also like to thank Professor Asao Ando, Professor Fukuyama Kei and Dr. Yang Zhang for their suggestions, and we appreciate the suggestions from the editor-in-chief on the submitted paper.

\section{REFERENCES}

[1] Ahmed, A. M., and Ismail S., "Socio-economic determinants of labor mobility in Pakistan," Pak. Dev. Rev., 32: 139-157 (1993).

[2] Azra, P., "Inter-provincial migration in Pakistan 1971-81," Pak. Dev. Rev., 32: 725-735 (1993).

[3] Arshad, M. F., "Regional patterns of industrialization in Pakistan," Pak. Econ. Soc. Rev., 27: 17-32 (1989).

[4] Chaudhary, M. A., "Economic growth and regional disparity in production activities in Pakistan," Pak. Econ. Soc. Rev., 28 105-120 (1990).

[5] De Kruijk, H., "Inequality in the four provinces of Pakistan," Pak. Dev. Rev., 25: 685-704 (1986).

[6] Economic Survey of Pakistan, Government of Pakistan, Finance division, Economic adviser's wing, Islamabad, various issues.

[7] Hoover, E. M., An Introduction to Regional Economics, Alfred A. Knoft, Inc., New York (1971).

[8] Khan, M Tariq Yousuf and Sasaki, K., "Roles of public capital in Pakistan economy: "productivity, investment and growth analysis"," Rev. Urban Reg. Dev. Stud., 13: 143-162 (2001).

[9] Khan, M Tariq Yousuf, "Regional disparity and the roles of public capital in Pakistan's economy," Ph.D. dissertation, Graduate School of Information Sciences, Tohoku University, Japan (2001).

[10] Kuznets, S., Economic Growth of Nations, Harvard University Press, Cambridge (1955).

[11] Labor Force Statistics, Federal Bureau of statistics, Government of Pakistan, various issues.

[12] Looney, R. E., and Winterford, D., "Infrastructure and regional development in Pakistan," Rev. Urban Reg. Dev. Stud., 5: 95114 (1993).

[13] Pasha, H., and Tariq, H., "Development ranking of districts in Pakistan," Pak. J. Appl. Econ., 1: 157-192 (1982).

[14] Sampath, R. K., and Anwer, M. S., "Inequalities in land distribution in Pakistan," Pak. Econ. Soc. Rev., 34, 119-143 (1996).

[15] United Nations Yearbook on National Accounts Statistics for Pakistan, 1988, 1997.

[16] Willamson, J. G., "Regional inequality and the process of national development: a description of the patterns," Econ. Dev. Cult. Change, 13: 1-84 (1965). 


\section{APPENDIX}

Table A.1. Regional sectoral production function.

\begin{tabular}{|c|c|c|c|c|c|c|}
\hline Sector/Region & $\begin{array}{c}\text { Equation/ } \\
\text { Description of } \\
\text { public capital }\end{array}$ & $\begin{array}{c}\text { Avg. share of } \\
\text { private capital } \\
\qquad\left(b_{r i}\right)\end{array}$ & $\begin{array}{l}\text { Constant } \\
\left(C_{r i}\right)\end{array}$ & $\begin{array}{l}\ln G_{t} \\
\left(\alpha_{r i}\right)\end{array}$ & $\begin{array}{c}\ln b_{r i} K_{i t} \ln L_{r i t} \\
\left(\beta_{r i}\right)\end{array}$ & $\bar{R}^{2}$ \\
\hline \multicolumn{7}{|l|}{ Agriculture } \\
\hline Region (1) & $(2-1) \mathrm{G}_{1}$ & 0.90 & $\begin{array}{c}5.8638 \\
(26.306)\end{array}$ & $\begin{array}{c}0.527 \\
(3.177)^{* *}\end{array}$ & $\begin{array}{c}0.041 \\
(2.269)^{*}\end{array}$ & 0.975 \\
\hline Region (2) & $(2-2) \mathrm{G}_{1}$ & 0.10 & $\begin{array}{c}4.018 \\
(13.831)^{* *}\end{array}$ & $\begin{array}{c}0.428 \\
(1.992)\end{array}$ & $\begin{array}{c}0.051 \\
(1.962)^{*}\end{array}$ & 0.954 \\
\hline \multicolumn{7}{|l|}{ Manufacturing } \\
\hline Region (1) & $(2-5) \mathrm{G}_{2}$ & 0.90 & $\begin{array}{c}1.476 \\
(5.587)^{* *}\end{array}$ & $\begin{array}{c}0.428 \\
(8.135)^{* *}\end{array}$ & $\begin{array}{c}0.049 \\
(7.803)^{* *}\end{array}$ & 0.982 \\
\hline Region (2) & $(2-6) \mathrm{G}_{2}$ & 0.10 & $\begin{array}{c}-2.925 \\
(-1.765)^{*}\end{array}$ & $\begin{array}{c}0.953 \\
(3.195)^{* * *}\end{array}$ & $\begin{array}{c}0.006 \\
(1.191)\end{array}$ & 0.884 \\
\hline
\end{tabular}

** denotes significant at $1 \%$ level $\quad{ }^{*}$ denotes significant at $5 \%$ level

Continued

\begin{tabular}{|c|c|c|c|c|c|c|}
\hline Sector/Region & $\begin{array}{c}\text { Equation/ } \\
\text { Description of } \\
\text { public capital }\end{array}$ & $\begin{array}{c}\text { Avg. share of } \\
\text { private capital } \\
\qquad\left(b_{r i}\right)\end{array}$ & $\begin{array}{l}\text { Constant } \\
\left(C_{r i}\right)\end{array}$ & $\begin{array}{l}\ln G_{t} \\
\left(\alpha_{r i}\right)\end{array}$ & $\begin{array}{c}\ln b_{r i} K_{i t} \ln L_{r i t} \\
\left(\beta_{r i}\right)\end{array}$ & $\bar{R}^{2}$ \\
\hline \multicolumn{7}{|l|}{ Construction } \\
\hline Region (1) & $(2-7) \mathrm{G}_{3}$ & 0.90 & $\begin{array}{c}3.084 \\
(6.221)^{* *}\end{array}$ & $\begin{array}{c}0.615 \\
(7.998)^{* *}\end{array}$ & $\begin{array}{c}0.009 \\
(1.931)^{*}\end{array}$ & 0.946 \\
\hline Region (2) & $(2-8) \mathrm{G}_{3}$ & 0.10 & $\begin{array}{c}1.155 \\
(1.893)^{*}\end{array}$ & $\begin{array}{c}0.681 \\
(5.480)\end{array}$ & $\begin{array}{c}0.011 \\
(1.887)^{*}\end{array}$ & 0.882 \\
\hline \multicolumn{7}{|l|}{ Energy } \\
\hline Region (1) & $(2-9) \mathrm{G}$ & 0.80 & $\begin{array}{c}-8.737 \\
(-7.342)^{* *}\end{array}$ & $\begin{array}{c}1.385 \\
(12.694)^{* *}\end{array}$ & $\begin{array}{c}0.007 \\
(1.549)\end{array}$ & 0.907 \\
\hline Region (2) & $(2-10) \mathrm{G}$ & 0.20 & $\begin{array}{c}-21.620 \\
(-12.784)^{* *}\end{array}$ & $\begin{array}{r}2.369 \\
(15.309)^{* * *}\end{array}$ & $\begin{array}{c}0.004 \\
(1.248)\end{array}$ & 0.943 \\
\hline
\end{tabular}

** denotes significant at $1 \%$ level ${ }^{*}$ denotes significant at $5 \%$ level

Continued

\begin{tabular}{|c|c|c|c|c|c|c|}
\hline Sector/Region & $\begin{array}{c}\text { Equation/ } \\
\text { Description of } \\
\text { public capital }\end{array}$ & $\begin{array}{c}\text { Avg. share of } \\
\text { private capital } \\
\qquad\left(b_{r i}\right)\end{array}$ & $\begin{array}{l}\text { Constant } \\
\qquad\left(C_{r i}\right)\end{array}$ & $\begin{array}{l}\ln G_{t} \\
\left(\alpha_{r i}\right)\end{array}$ & $\begin{array}{c}\ln b_{r i} K_{i t} \ln L_{r i t} \\
\left(\beta_{r i}\right)\end{array}$ & $\bar{R}^{2}$ \\
\hline \multicolumn{7}{|l|}{ Transport } \\
\hline Region (1) & $(2-11) \mathrm{G}$ & 0.95 & $\begin{array}{c}-3.902 \\
(-4.867)\end{array}$ & $\begin{array}{c}0.981 \\
(7.369)^{* * *}\end{array}$ & $\begin{array}{c}0.029 \\
(2.015)\end{array}$ & 0.962 \\
\hline Region (2) & $(2-12) \mathrm{G}$ & 0.05 & $\begin{array}{c}-9.908 \\
(-4.009)\end{array}$ & ${ }^{1.422}{ }^{\text {** }}$ & $\begin{array}{c}0.016 \\
(1.292)\end{array}$ & 0.967 \\
\hline \multicolumn{7}{|l|}{ Transport } \\
\hline Region (1) & $(2-13) \mathrm{G}_{2}$ & 0.90 & $\begin{array}{c}-0.911 \\
(-1.852)\end{array}$ & $\begin{array}{c}0.722 \\
(7.175)^{\text {*** }}\end{array}$ & $\begin{array}{c}0.036 \\
(2.603)^{\text {** }}\end{array}$ & 0.961 \\
\hline Region (2) & $(2-14) \mathrm{G}_{2}$ & 0.10 & $\begin{array}{c}-4.628 \\
(-3.248)^{* *}\end{array}$ & $\begin{array}{c}0.894 \\
(3.154)^{* * *}\end{array}$ & $\begin{array}{c}0.057 \\
(1.078)\end{array}$ & 0.962 \\
\hline
\end{tabular}

** denotes significant at $1 \%$ level ${ }^{*}$ denotes significant at $5 \%$ level

Continued

\begin{tabular}{|c|c|c|c|c|c|c|}
\hline Sector/Region & $\begin{array}{c}\text { Equation/ } \\
\text { Description of } \\
\text { public capital }\end{array}$ & $\begin{array}{l}\text { Avg. share of } \\
\text { private capital } \\
\qquad\left(b_{r i}\right)\end{array}$ & $\begin{array}{l}\text { Constant } \\
\qquad\left(C_{r i}\right)\end{array}$ & $\begin{array}{l}\ln G_{t} \\
\left(\alpha_{r i}\right)\end{array}$ & $\begin{array}{c}\ln b_{r i} K_{i t} \ln L_{r i t} \\
\left(\beta_{r i}\right)\end{array}$ & $\bar{R}^{2}$ \\
\hline \multicolumn{7}{|l|}{ Trade } \\
\hline Region (1) & $(2-15) \mathrm{G}_{3}$ & 0.90 & $\begin{array}{c}3.786 \\
(15.244)\end{array}$ & $\begin{array}{c}0.506 \\
(12.229)^{* *}\end{array}$ & $\begin{array}{c}0.034 \\
(12.670)^{* *}\end{array}$ & 0.993 \\
\hline Region (2) & $(2-16) \mathrm{G}_{3}$ & 0.10 & $\begin{array}{c}6.559 \\
(26.198)^{* *}\end{array}$ & $\begin{array}{c}0.074 \\
(1.889)^{*} \\
\end{array}$ & $\begin{array}{c}0.057 \\
(13.729)^{* *}\end{array}$ & 0.980 \\
\hline \multicolumn{7}{|l|}{ Services } \\
\hline Region (1) & $(2-17) \mathrm{G}_{3}$ & 0.90 & $\begin{array}{c}3.477 \\
(22.021)^{* *}\end{array}$ & $\begin{array}{c}0.414 \\
(12.035)^{* * *}\end{array}$ & $\begin{array}{c}0.037 \\
(16.430)^{* *}\end{array}$ & 0.995 \\
\hline Region (2) & $(2-18) \mathrm{G}_{3}$ & 0.10 & $\begin{array}{c}3.406 \\
(9.413)^{* *}\end{array}$ & $\begin{array}{c}0.311 \\
(4.106)^{* * *}\end{array}$ & $\begin{array}{c}0.049 \\
(6.240)^{* * *}\end{array}$ & 0.975 \\
\hline
\end{tabular}

*** denotes significant at $1 \%$ level $\quad{ }^{*}$ denotes significant at $5 \%$ level 
Table A.2. Regional sectoral labor allocation (Region 1).

\begin{tabular}{c|ccccccc}
\hline Parameter/Sector & Sector-1 & Sector-2 & Sector-3 & Sector-4 & Sector-5 & Sector-6 & Sector-7 \\
\hline$\alpha$ & -0.151 & -0.161 & -0.820 & -0.936 & -2.647 & -0.132 & 0.084 \\
& $(-2.068)$ & $(-0.195)$ & $(-2.315)$ & $(-1.217)$ & $(-3.727)$ & $(-0.542)$ & $(0.176)$ \\
\hline$\beta$ & 0.568 & 0.933 & 0.720 & 0.849 & 0.114 & 0.930 & 1.053 \\
& $(4.037)$ & $(2.887)$ & $(6.167)$ & $(4.915)$ & $(2.464)$ & $(7.012)$ & $(4.003)$ \\
\hline$\gamma$ & 0.326 & 0.008 & 0.142 & 0.180 & 0.044 & -0.008 & 0.127 \\
& $(3.130)$ & $(2.017)$ & $(1.906)$ & $(1.158)$ & $(2.440)$ & $(-0.049)$ & $(1.482)$ \\
\hline $\bar{R}^{2}$ & 0.774 & 0.763 & 0.944 & 0.563 & 0.634 & 0.842 & 0.775 \\
\hline
\end{tabular}

\section{Simulation Results}

Table A.3. National per capita GDP (Rupees).

\begin{tabular}{ccccccccc}
\hline Year & 1973 & 1975 & 1978 & 1982 & 1986 & 1990 & 1995 & 1997 \\
\hline Estimated & 2920 & 3040 & 3376 & 4059 & 4571 & 5091 & 5853 & 6097 \\
Scenario-1 & 3736 & 3967 & 4508 & 5584 & 6417 & 7282 & 8503 & 8906 \\
Scenario-2 & 3477 & 3288 & 3510 & 4168 & 4678 & 5193 & 5946 & 6191 \\
Scenario-3 & 4008 & 4099 & 4580 & 5638 & 6465 & 7320 & 8526 & 8926 \\
Scenario-4 & 2920 & 3041 & 3379 & 4063 & 4602 & 5132 & 5882 & 6126 \\
\hline
\end{tabular}

Table A.4. Per capita GDP in region-1 (Rupees).

\begin{tabular}{ccccccccc}
\hline Year & 1973 & 1975 & 1978 & 1982 & 1986 & 1990 & 1995 & 1997 \\
\hline Estimated & 3017 & 3157 & 3544 & 4300 & 4830 & 5384 & 6184 & 6426 \\
Scenario-1 & 4040 & 4302 & 4926 & 6142 & 7047 & 8003 & 9344 & 9770 \\
Scenario-2 & 2779 & 2920 & 3285 & 3986 & 4470 & 4974 & 5700 & 5917 \\
Scenario-3 & 3887 & 4147 & 4753 & 5923 & 6788 & 7700 & 8977 & 9380 \\
Scenario-4 & 3017 & 3157 & 3548 & 4305 & 4859 & 5425 & 6216 & 6457 \\
\hline
\end{tabular}

Table A.5. Per capita GDP in region-2 (Rupees).

\begin{tabular}{ccccccccc}
\hline Year & 1973 & 1975 & 1978 & 1982 & 1986 & 1990 & 1995 & 1997 \\
\hline Estimated & 2538 & 2569 & 2686 & 3061 & 3475 & 3838 & 4409 & 4643 \\
Scenario-1 & 2551 & 2649 & 2849 & 3357 & 3874 & 4346 & 5041 & 5333 \\
Scenario-2 & 6199 & 4688 & 4327 & 4770 & 5345 & 5865 & 6678 & 7019 \\
Scenario-3 & 4481 & 3885 & 3853 & 4430 & 5061 & 5646 & 6507 & 6873 \\
Scenario-4 & 2538 & 2570 & 2691 & 3064 & 3513 & 3876 & 4427 & 4665 \\
\hline
\end{tabular}

Table A.6. Labor in region-1 (million).

\begin{tabular}{cccccccc}
\hline Year & 1975 & 1978 & 1982 & 1986 & 1990 & 1995 & 1997 \\
\hline Estimated & 17.000 & 18.748 & 20.909 & 23.318 & 25.997 & 29.789 & 31.760 \\
Scenario-1 & 17.216 & 19.035 & 21.260 & 23.744 & 26.503 & 30.404 & 32.429 \\
Scenario-2 & 16.945 & 18.700 & 20.881 & 23.307 & 25.998 & 29.803 & 31.778 \\
Scenario-3 & 17.190 & 19.016 & 21.255 & 23.750 & 26.518 & 30.429 & 32.458 \\
Scenario-4 & 16.999 & 18.749 & 20.911 & 23.322 & 26.006 & 29.799 & 31.769 \\
\hline
\end{tabular}


Table A.7. Labor in region-2 (million).

\begin{tabular}{cccccccc}
\hline Year & 1975 & 1978 & 1982 & 1986 & 1990 & 1995 & 1997 \\
\hline Estimated & 3.871 & 4.160 & 4.331 & 4.359 & 4.345 & 4.307 & 4.336 \\
Scenario-1 & 3.853 & 4.065 & 4.105 & 4.010 & 3.910 & 3.801 & 3.803 \\
Scenario-2 & 2.905 & 2.746 & 2.762 & 2.769 & 2.769 & 2.761 & 2.787 \\
Scenario-3 & 3.213 & 3.123 & 3.090 & 3.018 & 2.954 & 2.887 & 2.895 \\
Scenario-4 & 3.872 & 4.157 & 4.323 & 4.344 & 4.312 & 4.276 & 4.310 \\
\hline
\end{tabular}

Table A.8. Population in region-1 (million).

\begin{tabular}{cccccccc}
\hline Year & 1975 & 1978 & 1982 & 1986 & 1990 & 1995 & 1997 \\
\hline Estimated & 56.789 & 62.107 & 68.647 & 76.077 & 84.354 & 96.028 & 102.124 \\
Scenario-1 & 56.790 & 62.112 & 68.663 & 76.112 & 84.414 & 96.126 & 102.240 \\
Scenario-2 & 56.800 & 62.175 & 68.803 & 76.319 & 84.675 & 96.444 & 102.580 \\
Scenario-3 & 56.796 & 62.155 & 68.762 & 76.265 & 84.616 & 96.387 & 102.525 \\
Scenario-4 & 56.789 & 62.107 & 68.647 & 76.078 & 84.356 & 96.033 & 102.130 \\
\hline
\end{tabular}

Table A.9. Population in region-2 (million).

\begin{tabular}{cccccccc}
\hline Year & 1975 & 1978 & 1982 & 1986 & 1990 & 1995 & 1997 \\
\hline Estimated & 14.709 & 16.278 & 18.194 & 20.295 & 22.567 & 25.685 & 27.289 \\
Scenario-1 & 14.708 & 16.273 & 18.178 & 20.259 & 22.504 & 25.582 & 27.168 \\
Scenario-2 & 14.699 & 16.211 & 18.035 & 20.046 & 22.231 & 25.248 & 26.809 \\
Scenario-3 & 14.702 & 16.231 & 18.077 & 20.101 & 22.293 & 25.309 & 26.868 \\
Scenario-4 & 14.709 & 16.278 & 18.194 & 20.294 & 22.564 & 25.679 & 27.283 \\
\hline
\end{tabular}

Table A.10. National Private capital stock (Rupees in billion).

\begin{tabular}{cccccccc}
\hline Year & 1975 & 1978 & 1982 & 1986 & 1990 & 1996 & 1997 \\
\hline Estimated & 209 & 228 & 274 & 360 & 463 & 645 & 732 \\
Scenario-1 & 217 & 250 & 325 & 453 & 612 & 890 & 1025 \\
Scenario-2 & 213 & 235 & 284 & 373 & 478 & 665 & 754 \\
Scenario-3 & 219 & 254 & 330 & 460 & 619 & 899 & 1034 \\
Scenario-4 & 209 & 229 & 275 & 367 & 473 & 655 & 742 \\
\hline
\end{tabular}

Table A.11. Private capital stock in region-1 (Rupees in billion).

\begin{tabular}{cccccccc}
\hline Year & 1975 & 1978 & 1982 & 1986 & 1990 & 1996 & 1997 \\
\hline Estimated & 188 & 205 & 246 & 324 & 416 & 581 & 659 \\
Scenario-1 & 195 & 225 & 292 & 408 & 551 & 801 & 922 \\
Scenario-2 & 149 & 165 & 198 & 261 & 335 & 466 & 528 \\
Scenario-3 & 175 & 203 & 264 & 368 & 496 & 719 & 827 \\
Scenario-4 & 188 & 206 & 247 & 330 & 425 & 589 & 668 \\
\hline
\end{tabular}

Table A.12. Private capital stock in region-2 (Rupees in billion).

\begin{tabular}{c|ccccccc}
\hline Year & 1975 & 1978 & 1982 & 1986 & 1990 & 1996 & 1997 \\
\hline Estimated & 21 & 23 & 27 & 36 & 46 & 65 & 73 \\
Scenario-1 & 22 & 25 & 32 & 45 & 61 & 89 & 102 \\
Scenario-2 & 64 & 71 & 85 & 112 & 143 & 200 & 226 \\
Scenario-3 & 44 & 51 & 66 & 92 & 124 & 180 & 207 \\
Scenario-4 & 21 & 23 & 27 & 37 & 47 & 65 & 74 \\
\hline
\end{tabular}

